\title{
Effect of reduced herbicide rates on weed control, environmental impact and profitability of corn
}

\author{
Nader Soltani, Richard J. Vyn, Laura L. Van Eerd, Christy Shropshire, and \\ Peter H. Sikkema
}

\begin{abstract}
University of Guelph Ridgetown Campus, 120 Main Street East, Ridgetown, Ontario, Canada NOP 2CO
(e-mail: nsoltani@uoguelph.ca). Received 8 December 2008, accepted 14 April 2009.
\end{abstract}

\begin{abstract}
Soltani, N., Vyn, R. J., Van Eerd, L. L., Shropshire, C. and Sikkema, P. H. 2009. Effect of reduced herbicide rates on weed control, environmental impact and profitability of corn. Can. J. Plant Sci. 89: 969-975. A study was conducted over a 3-yr period $(2003,2004$, and 2005) to evaluate the effect of reduced herbicide rates - 20, 40, 60, 80, and 100\% of the manufacturer's recommended rate (MRR) - on weed biomass reduction, environmental impact (EI), yield, and profitability of corn (Zea mays L.) in Ontario. The herbicide rate required to provide $95 \%$ biomass reduction of velvetleaf (Abutilon theophrasti Medic.), redroot pigweed (Amaranthus retroflexus L.), common ragweed (Ambrosia artemisiifolia L.), common lambsquarters (Chenopodium album L.), and annual grasses was $92,30,41,28$, and $83 \%$ of the MRR for isoxaflutole plus atrazine, $>200,119,23,23$, and $117 \%$ of the MRR for dimethenamid plus dicamba/atrazine, $141,72,46,45$, and $>200 \%$ of the MRR for glufosinate plus atrazine, and 81, 29, 18, 24, and 88\% of the MRR for nicosulfuron/rimsulfuron plus dicamba/ diflufenzopyr, respectively. The herbicide rate required to provide $95 \%$ of weed-free corn yield was $61,22,130$, and $11 \%$ of the MRR for isoxaflutole plus atrazine, dimethenamid plus dicamba/atrazine, glufosinate plus atrazine, and nicosulfuron/ rimsulfuron plus dicamba/diflufenzopyr, respectively. Nicosulfuron/rimsulfuron plus dicamba/diflufenzopyr had the lowest EI. The results of profitability analysis suggested that the MRR rates do not tend to maximize profit margins. In most cases, there were no significant differences in profit margins for treatments with $40,60,80$, and $100 \%$ of the MRR.
\end{abstract}

Key words: Atrazine, dicamba, diflufenzopyr, dimethenamid, glufosinate, nicosulfuron, rimsulfuron, Zea mays L.

Soltani, N., Vyn, R. J., Van Eerd, L. L., Shropshire, C. et Sikkema, P. H. 2009. Incidence d'un plus faible taux d'application des herbicides sur la lutte contre les mauvaises herbes, l'environnement et la rentabilité du maïs. Can. J. Plant Sci. 89: 969-975. Pendant trois ans (2003, 2004 et 2005), les auteurs ont évalué les effets d'un plus faible taux d'application des herbicides - 20, $40,60,80$ et $100 \%$ du taux recommandé par le fabricant (TRF) - sur la biomasse des adventices, sur l'environnement et sur la rentabilité du maïs (Zea mays L.), en Ontario. Le taux d'application requis pour obtenir une réduction de $95 \%$ de la biomasse de l'abutilon (Abutilon theophrasti Medic.), de l'amarante réfléchie (Amaranthus retroflexus L.), de la petite herbe à poux (Ambrosia artemisiifolia L.), du chénopode blanc (Chenopodium album L.) et des graminées annuelles correspond respectivement à 92, 30, 41, 28 et $83 \%$ du TRF pour l'isoxaflutole additionné d'atrazine, à $>200,119,23,23$, et $117 \%$ du TRF pour le diméthènamide additionné de dicamba/atrazine, à 141, 72, 46, 45 et $>200 \%$ du TRF pour le glufosinate additionné d'atrazine, et à $81,29,18,24$ et $88 \%$ du TRF pour le nicosulfuron/rimsulfuron additionné de dicamba/ diflufenzopyr. Le taux d'application nécessaire pour obtenir un rendement de $95 \%$ en maïs sans mauvaises herbes correspond respectivement à $61,22,130$ et $11 \%$ du TRF pour l'isoxaflutole additionné d'atrazine, le diméthènamide additionné de dicamba/atrazine, le glufosinate additionné d'atrazine et le nicosulfuron/rimsulfuron additionné de dicamba/ diflufenzopyr. Le nicosulfuron/rimsulfuron additionné de dicamba/diflufenzopyr a le plus faible impact sur l'environnement. Les résultats de l'analyse de rentabilité laissent croire que le TRF n'a pas tendance à maximiser la marge bénéficiaire. Dans la plupart des cas, la marge bénéficiaire ne varie pas sensiblement entre les taux d'application correspondant à 40, 60 , 80 et $100 \%$ du TRF.

Mots clés: Atrazine, dicamba, diflufenzopyr, diméthènamide, glufosinate, nicosulfuron, rimsulfuron, Zea mays L.

Corn production is important to the economy of Ontario, where nearly $63 \%$ of Canada's corn is produced (McGee 2007). In 2007, corn producers in Ontario planted nearly 850000 ha of corn and harvested 6985 $400 \mathrm{t}$ of grain corn (Anonymous 2007). Effective weed control is an important component of profitable corn production. Current troublesome weeds include common lambsquarters, redroot pigweed, common ragweed, velvetleaf, ladysthumb (Polygonum persicaria L.), wild mustard (Sinapis arvensis L.), annual nightshades (Solanum spp.), and annual grasses such as foxtails (Setaria spp.) [Ontario Ministry of Agriculture, Food and Rural Affairs (OMAFRA) 2006].

When this study was initiated, growers commonly used isoxaflutole plus atrazine preemergence (PRE)

\footnotetext{
Abbreviations: DAE, days after emergence; EI, environmental impact; EIQ, environmental impact quotient; MRR, manufacturer's recommended rate; OM, organic matter; POST, postemergence; PRE, preemergence; WAT, weeks after treatment
} 
$\left(80+800\right.$ g a.i. ha $\left.{ }^{-1}\right)$, dimethenamid plus dicamba/ atrazine postemergence (POST) $1(1000+1800 \mathrm{~g}$ a.i. $\left.\mathrm{ha}^{-1}\right)$, glufosinate plus atrazine POST $2(400+840 \mathrm{~g}$ a.i. $\mathrm{ha}^{-1}$ ) and nicosulfuron/rimsulfuron plus dicamba/ diflufenzopyr POST $3\left(25+200 \mathrm{~g}\right.$ a.i. $\left.\mathrm{ha}^{-1}\right)$ for weed control in corn. Depending on numerous factors including weed species present, weed size at the time of application, weed density, and environmental conditions, applying herbicides at lower than manufacturer's recommended rate (MRR) can provide adequate weed control and increase crop profitability while reducing the risk of crop injury (Sikkema et al. 2007; Soltani et al. 2007a, b). For these weed management strategies to succeed, growers must consistently get acceptable weed control and an increase in profitability. Some researchers have found adequate weed control and improved economic returns when herbicides are reduced 50 to $70 \%$ of the MRR (Forcella 1995; Hamill and Zhang 1995; Schans and Weide 1999). Other studies have shown that under some environmental conditions, herbicide rates can be reduced as much as 80 to $90 \%$ without a significant loss in the yield of corn (Weide et al. 1995; Alm et al. 2000).

Beyond efficacy and economic considerations, many growers prefer to utilize weed management options that minimize risks to farm workers, consumers, and the environment. The environmental impact quotient (EIQ) characterizes the risk to the aforementioned targets by considering pesticide physiochemical and toxicological characteristics, such as half-life, leaching, run-off potential, mode of action, toxicity to non-target organisms, and application method (Kovach et al. 1992). The environmental impact (EI) of a particular pesticide treatment is a product of the EIQ and the application dose, thus providing one number indicating the magnitude of relative risk. A higher EI indicates a greater risk of detrimental impact. When compared with two other environmental risk indices, the EIQ has been shown to be similar in pesticide ranking of risk. The EIQ has been successfully employed to compare environmental risk of rotations and/or production systems (Edwards-Jones and Howells 2001; De Jong and De Snoo 2002; Sikkema et al. 2007, Soltani et al. 2007a, b), as well as changes in pesticide use over time (Gallivan et al. 2001; Brimner et al. 2005). Based on crop yield, economics, and EI, the most advantageous herbicide program can be identified.

The objective of this study was to evaluate the effect of reduced rates $-20,40,60,80$, and $100 \%$ of the MRR of isoxaflutole plus atrazine, dimethenamid plus dicamba/atrazine, glufosinate plus atrazine, and nicosulfuron/rimsulfuron plus dicamba/diflufenzopyr on weed control, environmental impact, yield, and profitability of corn in Ontario.

\section{MATERIALS AND METHODS}

Three field trials were conducted at the University of Guelph, Ridgetown Campus, Ridgetown, Ontario, from 2003 to 2005. The soil was a Watford-Brady (Gleyed Brunisolic Grey-Brown Luvisol, mixed, mesic, loamy, and imperfectly drained) with $33 \%$ sand, $33 \%$ silt, $34 \%$ clay, $5.7 \%$ organic matter (OM), and $\mathrm{pH} 6.6$ in 2003; $38 \%$ sand, $35 \%$ silt, $27 \%$ clay, $5.2 \%$ OM, and pH 7.3 in 2004 ; and $46 \%$ sand, $34 \%$ silt, $20 \%$ clay, $3.8 \%$ OM, and $\mathrm{pH} 7.2$ in 2005. Seedbed preparation at all sites consisted of fall moldboard plowing followed by two passes with a field cultivator in the spring.

The study was established as a two-way factorial in a randomized complete block design with four replications. Factor one was herbicides: isoxaflutole plus atrazine PRE $\left(80+800 \mathrm{~g}\right.$ a.i. $\left.\mathrm{ha}^{-1}\right)$, dimethenamid plus dicamba/atrazine POST $1(1000+1800 \mathrm{~g}$ a.i. $\left.\mathrm{ha}^{-1}\right)$, glufosinate plus atrazine POST $2(400+840 \mathrm{~g}$ a.i. ha $\left.^{-1}\right)$, and nicosulfuron/rimsulfuron plus dicamba/ diflufenzopyr POST $3\left(25+200 \mathrm{~g}\right.$ a.i. ha $\left.{ }^{-1}\right)$; factor two was herbicide rate $(0,20,40,60,80$, and $100 \%$ of the MRR). Nicosulfuron/rimsulfuron plus dicamba/diflufenzopyr treatments included a nonionic surfactant (Agral $90^{\circledR}$ ) at $0.25 \% \mathrm{vol} / \mathrm{vol}$ and urea ammonium nitrate (UAN $28 \%$ ) at $1.25 \% \mathrm{vol} / \mathrm{vol}$. Each plot was $3 \mathrm{~m}$ wide and $8 \mathrm{~m}$ long, and consisted of four rows of Liberty Link Pioneer 36H69 corn spaced $0.75 \mathrm{~m}$ apart. Corn was planted at a rate of 76000 seeds ha ${ }^{-1}$ on 2003 May 19, 2004 May 29, and 2005 May 10.

Herbicide treatments were applied using a $\mathrm{CO}_{2-}$ pressurized backpack sprayer calibrated to deliver $200 \mathrm{~L} \mathrm{ha}^{-1}$ aqueous solution at $240 \mathrm{kPa}$. The boom was $1.5 \mathrm{~m}$ long with four ULD120-02 nozzles (ULD12002 nozzle tips; Spraying Systems Co., Wheaton, IL.) spaced $0.5 \mathrm{~m}$ apart. The PRE herbicides were applied 1 to $2 \mathrm{~d}$ after planting. The POST 1,2, and 3 herbicides were applied at the spike to one-leaf, three- to four-leaf, and five- to six-leaf stage, respectively. Weed-free plots were maintained weed-free during the growing season by hand-hoeing as required.

At 8 wk after treatment (WAT), weed biomass (shoot dry weight) from weed populations naturally occurring in each plot was determined by cutting the plants at the soil surface from two $0.25-\mathrm{m}^{-2}$ quadrats. Weeds were separated by species, combined from the two quadrats in each plot, dried at $60^{\circ} \mathrm{C}$ to constant weight, and dry weight was recorded. Yield was measured at crop maturity by harvesting the two middle rows of each plot with a plot combine on 2003 Oct. 25, 2004 Nov. 08, and 2005 Oct. 26. Yields were adjusted to $15.5 \%$ moisture content.

Data were analyzed using Proc MIXED procedure of SAS Institute, Inc. (1999) software to determine whether or not environments and/or herbicides could be combined for the regression analysis. Dry weight data were log-transformed to meet assumptions of normality (Bartlett 1947). Yield did not need to be transformed.

Environments were combined for the regression analyses where the environment by herbicide by rate interaction and the herbicide by rate interaction were not significant. If environments could not be combined over all herbicides, each herbicide was analyzed separately, and environments within that herbicide were 
combined if the environment by rate interaction was not significant.

Proc NLIN (SAS Institute, Inc. 1999) was used to perform regression analyses. Nonlinear curves were fitted to the data and used to predict the percent herbicide rate that would give 80 and $95 \%$ reduction in weed biomass (measured as percent dry weight), and percent yield relative to the optimum scenario (weedfree). For the purpose of regression, the weed-free check was assigned a value of $200 \%$ for herbicide rate. This was done to help define the upper asymptote for weed control and percent yield, and the lower asymptote for percent dry weight.

For dry weight (biomass), both actual dry weight and dry weight as a percentage of the weedy check were compared, as well as a rate-response equation and an exponential decay equation. Overall, the rate-response equation using percent dry weight yielded the best fit. This was estimated from the models' $R^{2}$ values. The equation used was:

$$
y=d /\left(1+\exp \left(b^{*}(\ln (\text { rate }+1)-\ln (c 50))\right)\right)
$$

where $d$ is the upper asymptote, $c 50$ is the herbicide rate that gives $50 \%$ reduction in dry weight and $b$ is the slope (rate of change). Using the values from the regression, the herbicide rates resulting in 80 and $95 \%$ reduction in dry weight were calculated using the equation:

$$
\text { reduction }(f)=\left[(f /(100-f))^{(1 / \mathrm{b})}\right] * c 50
$$

where $f=80$ or 95 .

For yield, both actual yield and yield as a percentage of the weed-free check were compared, as well as a rateresponse equation and a rectangular hyperbolic equation. The rate-response equation using percent yield gave the best fit, as estimated from the models' $R^{2}$ values. The equation used was the same as that for biomass reduction, and 80 and $95 \%$ yield were also calculated in the same manner.

\section{Environmental Impact}

The environmental risk for each herbicide treatment was determined using published EIQ values for all active ingredients (Kovach et al. 1992, 2004), except for isoxaflutole plus atrazine, which was calculated based on PRE application. The EI of each product was calculated by multiplying herbicide EIQ by the amount applied in $\mathrm{kg}$ a.i. $\mathrm{ha}^{-1}$. For products with more than one active ingredient, the EI was calculated by first summing EIQs at the appropriate proportion. The EI of tank-mix treatments was the sum of EIs for each product/herbicide.

For percent weed control data at either 4 or 8 WAT, an EI was calculated for each treatment at the rate that provided 80,90 , and $95 \%$ for each weed species. EI data were log-transformed prior to three-way analysis of variance (ANOVA) using the general linear model procedure (PROC GLM) of SAS Insitute, Inc. (1999) software on the following parameters: herbicide treatment, percent control $(80,90$, and $95 \%)$ and weed type. Differences between EI means were analyzed using Fisher's protected least significant difference (LSD). The type-I error rate was set at 0.05 .

\section{Profitability Analysis}

A profitability analysis was conducted to determine the percentage of the MRR for each set of treatments that generated the greatest profit margins over weed control costs. These margins were derived based on the reported yields, the average corn price received by farmers in Ontario between 2003 and 2005 (Agricorp. 2003-2005), herbicide costs, and application costs. Herbicide costs were calculated based on prices reported by AGRIS Co-operative Ltd. (2003-2005), while application costs were taken from OMAFRA (2003-2005).

Pairwise comparisons were made for each set of treatments using SPSS software (2003) to test for significant differences in average profit margins between the specified percentages of the MRR. Significant differences in profit margins within each set of treatments were tested using Fisher's protected LSD at the $5 \%$ level of significance. This analysis was performed separately for each of the four sets of treatments.

\section{RESULTS AND DISCUSSION}

\section{Weed Biomass}

Five weed species were present in at least two of the three environments and were included in the analysis. The Pest Management Regulatory Agency (PMRA) in Canada requires a minimum of $80 \%$ weed control for registration of new herbicides, but growers often demand $95 \%$ or greater control.

The herbicide rate required to provide $80 \%$ reduction in biomass of velvetleaf, redroot pigweed, common ragweed, common lambsquarters, and annual grasses was $28,11,29,16$, and $74 \%$ of the MRR for isoxaflutole plus atrazine, respectively (Table 1 ). The herbicide rate increased when $95 \%$ control was required. The herbicide rate required to provide $95 \%$ reduction in biomass of velvetleaf, redroot pigweed, common ragweed, common lambsquarters, and annual grasses was 92, 30, 41, 28, and $83 \%$ of the MRR for isoxaflutole plus atrazine, respectively (Table 1 ).

The herbicide rate required to provide $80 \%$ reduction in biomass of velvetleaf, redroot pigweed, common ragweed, common lambsquarters, and annual grasses was $121,36,17,15$, and $80 \%$ of the MRR for dimethenamid plus dicamba/atrazine, respectively (Table 1). The herbicide rate increased when $95 \%$ control was required. The herbicide rate required to provide $95 \%$ reduction in biomass of velvetleaf, redroot pigweed, common ragweed, common lambsquarters, and annual grasses was $>200,119,23,23$, and $117 \%$ of the MRR for dimethenamid plus dicamba/atrazine, 
respectively (Table 1). Greater than the MRR of dimethenamid plus dicamba/atrazine was required to provide $95 \%$ control of velvetleaf, redroot pigweed, and annual grasses, while $23 \%$ of MRR of dimethenamid plus dicamba/atrazine was sufficient to provide $95 \%$ biomass reduction of common ragweed and common lambsquarters.

The rate of glufosinate plus atrazine required to provide $80 \%$ reduction in biomass of velvetleaf, redroot pigweed, common ragweed, common lambsquarters, and annual grasses was $115,20,27,23$, and $194 \%$ of the MRR, respectively (Table 1). The herbicide rate increased when $95 \%$ control was required. The herbicide rate required to provide $95 \%$ reduction in biomass of velvetleaf, redroot pigweed, common ragweed, common lambsquarters, and annual grasses was 141, 72, 46, 45, and $>200 \%$ of the MRR for glufosinate plus atrazine, respectively (Table 1). The biomass of velvetleaf and annual grasses was not affected as much as other weed species when treated with glufosinate plus atrazine. Rates greater than the MRR were required to provide adequate control of these weed species (Table 1). Similar variation in the control of annual grasses with reduced herbicide rates has been reported (Sikkema et al. 2007). The full MRR of herbicides evaluated was generally required to provide $>90 \%$ control of grass weeds (Hamill et al. 2004; Sikkema et al. 2007).

The herbicide rate required to provide $80 \%$ reduction in biomass of velvetleaf, redroot pigweed, common ragweed, common lambsquarters, and annual grasses was $38,21,10,11$, and $69 \%$ of the MRR for nicosulfuron/rimsulfuron plus dicamba/diflufenzopyr, respectively (Table 1). The herbicide rate increased when $95 \%$ control was required. The herbicide rate required to provide $95 \%$ reduction in biomass of velvetleaf, redroot pigweed, common ragweed, common lambsquarters, and annual grasses was $81,29,18,24$, and $88 \%$ of the MRR for nicosulfuron/rimsulfuron plus dicamba/diflufenzopyr, respectively (Table 1). Greater than $80 \%$ of the MRR of nicosulfuron/rimsulfuron plus dicamba/diflufenzopyr was required to provide $95 \%$ control of velvetleaf and annual grasses, while less than $30 \%$ of MRR of nicosulfuron/rimsulfuron plus dicamba/diflufenzopyr was sufficient to provide $95 \%$ control of redroot pigweed, common ragweed, and common lambsquarters. In other studies, the full MRR of nicosulfuron and rimsulfuron with other herbicide tank-mixes were required to provide $90 \%$ or greater reduction in weed density and biomass of velvetleaf, redroot pigweed, common ragweed, common lambsquarters, and annual grasses (Hamill et al. 2004; Sikkema et al. 2007). The weed density and biomass were more variable as the MRR was reduced to $25 \%$ of MRR (Hamill et al. 2004; Sikkema et al. 2007).

\section{Yield}

The herbicide rate required to provide $80 \%$ of the weedfree yield was $10,6,15$, and $4 \%$ of the MRR for 
Table 2. Predicted rate of isoxaflutole plus atrazine, dimethenamid plus dicamba/atrazine, glufosinate plus atrazine, and nicosulfuron/rimsulfuron plus dicamba/diflufenzopyr [as a percentage of the manufacturer's full-recommended rate (MRR)] needed to achieve 80 or $95 \%$ of weedfree corn yield (combined over all weed species), based on regression analysis

\begin{tabular}{lcc}
\hline Treatment & $\begin{array}{c}\text { MRR rate for } \\
80 \% \text { yield (\%) }\end{array}$ & $\begin{array}{c}\text { MRR rate for 95\% } \\
\text { yield (\%) }\end{array}$ \\
\hline $\begin{array}{l}\text { Isoxaflutole + atrazine } \\
\text { Dimethenamid + dicamba/ }\end{array}$ & 10 & 61 \\
$\quad$ atrazine & 6 & 22 \\
$\begin{array}{l}\text { Glufosinate + atrazine } \\
\text { Nicosulfuron/rimsulfuron } \\
\text { dicamba/diflufenzopyr }\end{array}$ & 15 & 130 \\
\hline
\end{tabular}

isoxaflutole plus atrazine, dimethenamid plus dicamba/ atrazine, glufosinate plus atrazine, and nicosulfuron/ rimsulfuron plus dicamba/diflufenzopyr, respectively (Table 2). The herbicide rate required to provide $95 \%$ of weed-free yield was significantly higher, $61,22,130$, and $11 \%$ of the MRR for isoxaflutole plus atrazine, dimethenamid plus dicamba/atrazine, glufosinate plus atrazine, and nicosulfuron/ rimsulfuron plus dicamba/ diflufenzopyr, respectively. Only $22 \%$ or less of the MRR for dimethenamid plus dicamba/atrazine and nicosulfuron/rimsulfuron plus dicamba/diflufenzopyr was sufficient to provide yields at $95 \%$ of the weedfree check. These results are similar to those of other studies that have shown that herbicide rates can be reduced as much as 15 to $90 \%$ of the MRR without any significant yield losses in corn under some environmental conditions (Forcella 1995; Hamill and Zhang 1995; Weide et al. 1995; Schans and Weide 1999; Alm et al. 2000; Zhang et al. 2000; Hamill et al. 2004). However, other research has shown yield reductions of 10 to $15 \%$ in corn under some environmental conditions when nicosulfuron plus rimsulfuron was tank-mixed with other herbicides at $25 \%$ of MRR (Sikkema et al. 2007).

\section{Environmental Impact}

The calculated EIQ for isoxaflutole and atrazine applied PRE was 13.3 and 13.6, respectively, which was approximately $40 \%$ lower than the POST application EIQ of 22.7 and 22.9, respectively. At the MRR for isoxaflutole plus atrazine treatment, the EI would increase from 11.9 to 20.1 when applied PRE vs. POST, respectively. This may influence interpretation of risk. This emphasizes the value of the level of risk that the EIQ calculation places on applying PRE vs. POST herbicides. This is an obvious limitation of the EIQ because the risk to consumers, farm workers, and the environment is assumed to be significantly lower by applying herbicides PRE, i.e., prior to crop emergence. The major assumption is that there is no herbicide uptake with herbicides applied PRE and, therefore, lower risks to consumers and farm workers. Atrazine and isoxaflutole are absorbed by the emerging corn plant.

For EI data based on weed control, there was a significant $(P<0.001)$ herbicide, percent control, and weed type effect, and a significant herbicide by weed interaction $(P<0.001)$. There were no other two-way or three-way interactions $(P \geq 0.54)$. The EI at 80,90 , and $95 \%$ weed control was 5.0, 6.6, and 7.4, respectively (data not shown). The EI for weed control at $80 \%$ was significantly lower than that at 90 or $95 \%$, which were not different from each other. Therefore, considering that corn yield was not significantly different at lower rates, one might consider reducing herbicide rates to minimize the EI.

Based on corn yields and percent weed control of different weed species, nicosulfuron/rimsulfuron plus dicamba/diflufenzopyr treatment had the lowest EI. The type of weed did not impact EI for isoxaflutole plus atrazine or nicosulfuron/rimsulfuron plus dicamba/diflufenzopyr. However, higher EIs were observed for adequate control of velvetleaf for glufosinate plus atrazine and velvetleaf and annual grasses for dimethenamid plus dicamba/atrazine (Table 3). Considering there was no difference in corn yield between the different treatments nor a difference between rates, provided a treatment was applied, the lowest rate of nicosulfuron/rimsulfuron plus dicamba/diflufenzopyr is recommended from an EI perspective.

\begin{tabular}{|c|c|c|c|c|}
\hline Weed & Isoxaflutole + atrazine & Dimethenamid + dicamba/atrazine & Glufosinate + atrazine & $\begin{array}{l}\text { Nicosulfuron/rimsulfuron }+ \\
\text { dicamba/diflufenzopyr }\end{array}$ \\
\hline & \multicolumn{4}{|c|}{ EI at MRR } \\
\hline All weeds & 11.9 & 58.3 & 30.5 & 5.4 \\
\hline Velvetleaf & \multicolumn{4}{|c|}{ EI at $\geq 80 \%$ control } \\
\hline Lambsquarters & $3.5 e$ & $12.6 c$ & $8.4 c d$ & $1.2 f$ \\
\hline Ragweed & $4.3 e$ & $14.7 b c$ & $12.4 c$ & $1.1 f$ \\
\hline Annual grasses & $5.9 \mathrm{de}$ & $25.9 a b$ & $11.2 c$ & $1.6 f$ \\
\hline
\end{tabular}

${ }^{\mathbf{z}}$ Data were log-transformed for analysis and back-transformed for presentation; means within a column followed by the same letter are not significantly different according to Fisher's protected LSD at $P<0.05$. 


\begin{tabular}{|c|c|c|c|c|}
\hline Rate $(\%)$ & Isoxaflutole + atrazine & Dimethenamid + dicamba/atrazine & Glufosinate + atrazine & Nicosulfuron/rimsulfuron + dicamba/diflufenzopyr \\
\hline 0 & $\$ 371.54 c$ & $\$ 371.54 c$ & $\$ 371.54 c$ & $\$ 371.54 c$ \\
\hline 20 & $\$ 881.84 b$ & $\$ 920.98 b$ & $\$ 850.19 b$ & $\$ 980.90 a b$ \\
\hline 40 & $\$ 973.20 a b$ & $\$ 979.06 a b$ & $\$ 937.70 a b$ & $\$ 1,010.51 a$ \\
\hline 60 & $\$ 1,028.09 a$ & $\$ 1,020.28 a$ & $\$ 924.09 a b$ & $\$ 968.84 a b$ \\
\hline 80 & $\$ 988.01 a$ & $\$ 978.18 a b$ & $\$ 947.75 a b$ & $\$ 918.14 b$ \\
\hline 100 & $\$ 932.86 a b$ & $\$ 954.55 a b$ & $\$ 1,015.57 a$ & $\$ 929.77 a b$ \\
\hline
\end{tabular}

$a-c$ Means within columns followed by the same letter are not significantly different $(P>0.05)$ according to Fisher's protected LSD.

\section{Profitability Analysis}

The profit margins over weed control costs are given in Table 4 for each herbicide combination by application rate. Within each of the four sets of treatments, the highest profit margins tended to occur around $60 \%$ of MRR of isoxaflutole plus atrazine and dimethenamid plus dicamba/atrazine treatments, the full MRR of glufosinate plus atrazine treatment, and the $40 \%$ of MRR of nicosulfuron/rimsulfuron plus dicamba/diflufenzopyr treatment. However, there were no significant differences in profit margins among the 40,60,80, and $100 \%$ of MRR rates for each treatment, with the exception of the nicosulfuron/rimsulfuron plus dicamba/diflufenzopyr treatment where there were no significant differences between the 20,40,60, and $100 \%$ of MRR rates. The lowest profit margins, aside from the weedy check, tended to occur in treatments with $20 \%$ of MRR.

Based on this study, the dimethenamid plus dicamba/ atrazine treatment had the highest EI, while nicosulfuron/rimsulfuron plus dicamba/diflufenzopyr treatment had the lowest EI. While the recommended rates of herbicide application may maximize weed control, the results of the profitability analysis suggested that these rates do not generate greater profit margins. In fact, in most cases there were no significant differences in profit margins between treatments with the $100 \%$ MRR and treatments with applications of 40 to $80 \%$ of the MRR. However, care is needed when making decisions to reduce herbicide rates based on short-term economic returns, as weed control failure and increased weed seed return can cause significant profit losses in the future. Integrated weed management that includes reduced rate herbicides and nonchemical options can be adapted to reduce risk of such failure.

\section{ACKNOWLEDGEMENTS}

Funding for this project was provided in part by the Ontario Corn Producers Association and the Agricultural Adaptation Council.

Agricorp. 2003-2005. Claim prices - corn. Agricorp, Guelph, ON.

AGRIS Co-operative Ltd. 2003-2005. Chemical prices. AGRIS Co-operative Ltd., Chatham, ON.
Alm, D. M., Wax, L. M. and Stoller, E. W. 2000. Weed suppression for weed management in corn (Zea mays) and soybean (Glycine max) production systems. Weed Technol. 14: 713-717.

Anonymous. 2007. Grain corn: area and production, by county. Ontario Ministry of Agriculture, Food and Rural Affairs. Toronto, ON. [Online] Available: http://www.omafra.gov.on.ca/english/stats/crops/ctygrcorn07.htm [2008 Oct. 30].

Bartlett, M. S. 1947. The use of transformations. Biometrics 3: 39-52.

Brimner, T. A., Gallivan, G. J. and Stephenson, G. R. 2005. Influence of herbicide-resistant canola on the environmental impact of weed management. Pest Manage. Sci. 61: 47-52.

De Jong, F. M. W. and De Snoo, G. R. 2002. A comparison of the environmental impact of pesticide use in integrated and conventional potato cultivation in the Netherlands. Agric. Ecosys. Environ. 91: 5-13.

Edwards-Jones, G. and Howells, O. 2001. The origin and hazard of inputs to crop protection in organic farming systems: are they sustainable? Agric. Syst. 67: 31-47.

Forcella F. 1995. Meeting the challenge of reduced herbicide use through dynamic bioeconomic weed management models. Proc. 9th EWRS Symp., Budapest, Hungary. pp. 641-646.

Gallivan, G. J., Surgeoner, G. A. and Kovach, J. 2001. Pesticide risk reduction on crops in the province of Ontario. J. Environ. Qual. 30: 798-813.

Hamill, A. S. and Zhang J. H. 1995. Herbicide reduction in metribuzin-based weed control programs in corn. Can. J. Plant Sci. 75: 927-933.

Hamill, A. S., Weaver, S. E., Sikkema, P. H., Swanton, C. J., Tardif, F. J. and Ferguson, G. M. 2004. Benefits and risks of economic vs. efficacious approaches to weed management in corn and soybean. Weed Technol. 18: 723-732.

Kovach, J., Petzoldt, C., Degni, J. and Tette, J. 1992. A method to measure the environmental impact of pesticides. New York's Food Life Sci. Bull. 139: 139-146.

Kovach, J., Petzoldt, C., Degni, J. and Tette, J. 2004. A method to measure the environmental impact of pesticides. In Table 2. List of pesticides. [Online] Available: http://nysipm.cornell.edu/publications/EIQ.html [2008 Oct. 30].

McGee, B. 2007. Estimated area, yield, production and farm value of specified field crops, Ontario, 1998-2007 (metric units). Ontario Ministry of Agriculture, Food and Rural Affairs. [Online] Available: http://www.omafra.gov.on.ca/english/stats/crops/ estimate_metric.htm [2008 Oct. 20].

Ontario Ministry of Agriculture, Food and Rural Affairs. 20032005. Field crop budget. Publ. 60. Toronto, ON. 
Ontario Ministry of Agriculture, Food and Rural Affairs. 2006. Guide to weed control. Publication 75. Toronto, ON. 396 pp. SAS Institute, Inc. 1999. The SAS system for windows. Release 8.0. SAS Institute, Inc., Cary, NC. 3884 pp.

Schans, V. D. and Weide, R. Y. 1999. Strong together. Weed control in maize: combine mechanical control and low application rates of herbicides. PAV Bull.-Akkerbouw. 2: 9-11.

Sikkema, P. H., Van Eerd, L. L., Vyn, R. D. and Weaver, S. E. 2007. A comparison of reduced rate and economic threshold approaches to weed management in a corn-soybean rotation. Weed Technol. 21: 647-655.

Soltani, N., Van Eerd, L. L., Vyn, R. D., Shropshire, C. and Sikkema, P. H. 2007a. Weed management in dry beans (Phaseolus vulgaris) with dimethenamid plus reduced doses of imazethapyr applied preplant incorporated. Crop Prot. 26: 739-745.

Soltani, N., Van Eerd, L. L., Vyn, R. D. Shropshire, C. and Sikkema, P. H. 2007b. Weed control, environmental impact and profitability of reduced rates of imazethapyr in combination with dimethenamid in dry beans. Can. J. Plant Sci. 87: 671-678.

SPSS Software. 2003. Version 16.0. SPSS Inc., Chicago, IL. Weide, R. Y., Krikke, A. and Wijnands, F. 1995. Technical and economic feasibility of mechanical weed control in arable farming in the Netherlands. Proc. 9th EWRS Symp. Budapest, Hungary. pp. 483-490.

Zhang, Z. H., Weaver, S. E. and Hamill A. S. 2000. Risks and reliability of using herbicides at below-labeled rates. Weed Technol. 14: 106-115. 